\title{
Histology of Sweet Orange Stem Pitting Caused by an Australian Isolate of Citrus tristeza virus
}

\author{
R. H. Brlansky, Professor, and D. S. Howd, Senior Biological Scientist, University of Florida, Citrus Research \& \\ Education Center, Lake Alfred 33850; P. Broadbent, formerly Principal Research Scientist, New South Wales Agri- \\ culture, EMAI, Camden 2570, Australia; and V. D. Damsteegt, Research Plant Pathologist, United States Depart- \\ ment of Agriculture-Agricultural Research Service, Foreign Disease and Weed Science Research Unit, Frederick, \\ MD 21702
}

\begin{abstract}
Brlansky, R. H., Howd, D. S., Broadbent, P., and Damsteegt, V. D. 2002. Histology of sweet orange stem pitting caused by an Australian isolate of Citrus tristeza virus. Plant Dis. 86:11691174 .

Some strains of the Citrus tristeza virus (CTV) cause stem pitting in sweet orange (Citrus sinensis (L.) Osbeck). This abnormality causes tree decline and reduction in fruit size and yield of affected citrus trees. Stem-pitting symptoms can occur on trunks, on all sizes of limbs, and on the twigs where fruit are produced. Variously sized pits or grooves in the wood often contain a yellow gum. Irregular growth of the phloem occurs in the area of these xylem pits. The histology of stem pitting caused by an Australian CTV isolate was studied in sweet orange using light and electron microscopy. Using scanning electron microscopy, details of the wood pits containing the gumming material were revealed. In thin sections of bark tissue, outgrowths of the phloem tissue were found at various intervals that corresponded to the pits in the wood. Higher numbers of viral inclusions were detected in the phloem outgrowths than were present in the other sieve elements.
\end{abstract}

Citrus tristeza virus (CTV) is a very important economic citrus pathogen (14). In the 1940s, a wilt and decline of sweet orange trees on sour orange rootstock appeared in many citrus areas of the world and research began on this disease $(9,20,27)$. At this same time, a stem- and wood-pitting disease of grapefruit (Citrus paradisi Macfad.) $(1,16,19)$ and a woodpitting and vein-flecking disease of limes was described and studied in Africa $(12,13)$. After inoculation of both grapefruit and lime seedlings by aphids from sweet orange trees on sour orange rootstock with tristeza decline and the appearance of stem-pitting symptoms, both stem-pitting diseases were considered to be caused by the tristeza virus $(5,26)$, even though the virus had not been described.

Corresponding author: R. H. Brlansky

E-mail: rhby@lal.ufl.edu

Current address of P. Broadbent: National Citrus Improvement Manager, Auscitrus, Mulgoa 2745, NSW Australia.

This research was supported by the Florida Agricultural Experiment Station and a grant from USDA-ARS, Specific Coop. Agreement \#586618-0-202, and approved for publication as Journal Series No. R-08476.

Accepted for publication 2 July 2002.

Publication no. D-2002-0819-03R

(C) 2002 The American Phytopathological Society
CTV is a phloem-limited closterovirus, 2,000 by $11 \mathrm{~nm}$ in size, that contains a single-stranded RNA of 19,226 to 19,302 nucleotides, with 12 possible open reading frames, encoding up to 19 proteins. Many different strains or isolates of the virus exist that produce a variety of biological symptoms in different citrus host plants (14). Symptoms range from no visible symptoms to severe visible symptoms which include seedling yellows, vein clearing, tree stunting, tree decline, tree death, and wood pitting of the trunk, branches, and stems (14). This latter symptom is most often referred to as stem pitting. Stem-pitting symptoms have been recorded in other plants, such as grape (8), cherry $(18,22,24)$, plum $(15,17)$, peach $(1,3,6$, $10,17,18)$, apple $(11,23)$, and apricot (7). Many of these stem-pitting diseases have been associated with, or are caused by, viruses. CTV isolates can induce stem pitting in a number of commercial hosts that include lime (C. aurantifolia (L.) Swingle), grapefruit (C. paradisi Macfad.), sweet orange (C. sinensis (L.) Osbeck), pummelo ( $C$. grandis (L.) Osbeck), and some pummelo hybrids (14). Other reports of stem pitting in citrus are associated with cristacortis (25) and Milam rootstock (6). Both conditions have no association with infection by CTV.

Little is known about the nature of CTVinduced stem pitting. A CTV isolate may cause stem pitting in one citrus host and not in others. Stem-pitting CTV isolates may cause loss in tree vigor, small fruit size, and decline. Stem pitting consists of longitudinal grooves or furrows in the xylem (wood) surface. Severe stem pitting may cause a rope-like appearance to the trunk of the tree, limbs, and twigs. In early studies, Schneider (20) found that stem pitting on Mexican lime occurs when a condition described as the chromatic condition occurs and spreads from the phloem parenchyma cells to the nearby meristematic tissue. The vascular cambium and some of the cambial cells and their derivatives become chromatic and sometimes hypertrophic. A mass of abnormal hypertrophic parenchyma cells with occasional chromatic cells occur where normal xylem and phloem should form. This disorganized tissue may remain attached to the bark when it is removed, leaving an elongated pit in the wood.

This study was initiated to examine the cytological changes in stem tissues of sweet orange caused by a severe CTV stem pitting isolate.

\section{MATERIALS AND METHODS}

A stem-pitting isolate of CTV (PB75) was obtained from Navel sweet orange trees (C. sinensis (L.) Osbeck) in Benyenda, Queensland, Australia. Field symptoms consisted of stem pitting of branches and twigs when the bark was removed from the wood. These symptoms were typical of those published for CTV (13). Fruit yield was reduced in the trees but fruit size was not noticeably reduced. Bud wood samples were collected and propagated in the greenhouse by grafting on a variety of biological indicator plants. As described previously (4), these included sweet orange, West Indian lime (C. aurantifolia (L.) Swingle), Duncan grapefruit ( $C$. paradisi Macfad.), Eureka lemon (C. limon (L.) Burm. f.), and bittersweet seville ( $C$. auratium L.). The greenhouse tests showed that the field isolate was positive for stem pitting on sweet orange, produced a severe vein-clearing reaction on West Indian lime, and was positive for the seedling yellows reaction on Eureka lemon, grapefruit, and bittersweet seville. Enzyme-linked immunosorbent assay (ELISA) tests (2) also were positive for CTV infection.

Single aphid transmissions using the brown citrus aphid (Toxoptera citricida Kirkaldy) as previously described (4) were 
performed to separate the CTV from other systemic pathogens and from the complex of CTV subisolates that exists in field isolates. Successive single aphid transmissions were done and the CTV isolate PB234 (Beltsville CTV Exotic Collection number B380) was derived from a single aphid transmission (fourth passage) from the PB75 field isolate. All three previous aphid-transmitted CTV subisolates prior to PB234 were orange stem pitting positive. In biological indicators, the PB234 subisolate produced a severe vein clearing in Mexican lime, no seedling yellows, and was positive for orange stem pitting. The isolate was propagated in healthy sweet orange seedlings in the greenhouse by bud graft inoculation. CTV infection in inoculated plants was determined using ELISA (2).

Bark and wood samples from branches (10 $\mathrm{mm}$ in diameter) and from trunks (20 $\mathrm{mm}$ in diameter) of greenhouse-infected and healthy sweet orange trees were collected for inclusion body detection, and light and electron microscopy. The stempitting and bark symptoms seen in these samples were the same as those seen in the field-infected Navel oranges and in the bud-inoculated greenhouse sweet oranges. The bark samples for inclusion body detection were cryosectioned and then stained with $0.1 \%$ Azure A in ethylene glycol monomethyl ether (eight parts) and $0.2 \mathrm{M}$ disodium phosphate (two parts), destained with 100\% ethanol and 2-methoxyethyl acetate, and mounted in Euparal (ASCO Laboratories, Gorton, Manchester, England). Bark and wood samples were fixed with $3 \%$ glutaraldehyde in $0.066 \mathrm{M}$ phosphate buffer, $\mathrm{pH}$ 6.8. Samples for light and transmission electron microscopy (TEM) were post-fixed with $2 \%$ osmium tetroxide in $0.066 \mathrm{M}$ phosphate buffer, $\mathrm{pH} 6.8$, dehydrated in a 25 to $100 \%$ acetone series, and embedded in Spurrs resin. Sections for light microscopy were stained with methylene blue/Azure A and basic fuchsin. Sections for TEM were stained with $15 \%$ uranyl acetate in methanol and Reynolds lead citrate. Bark and wood samples for
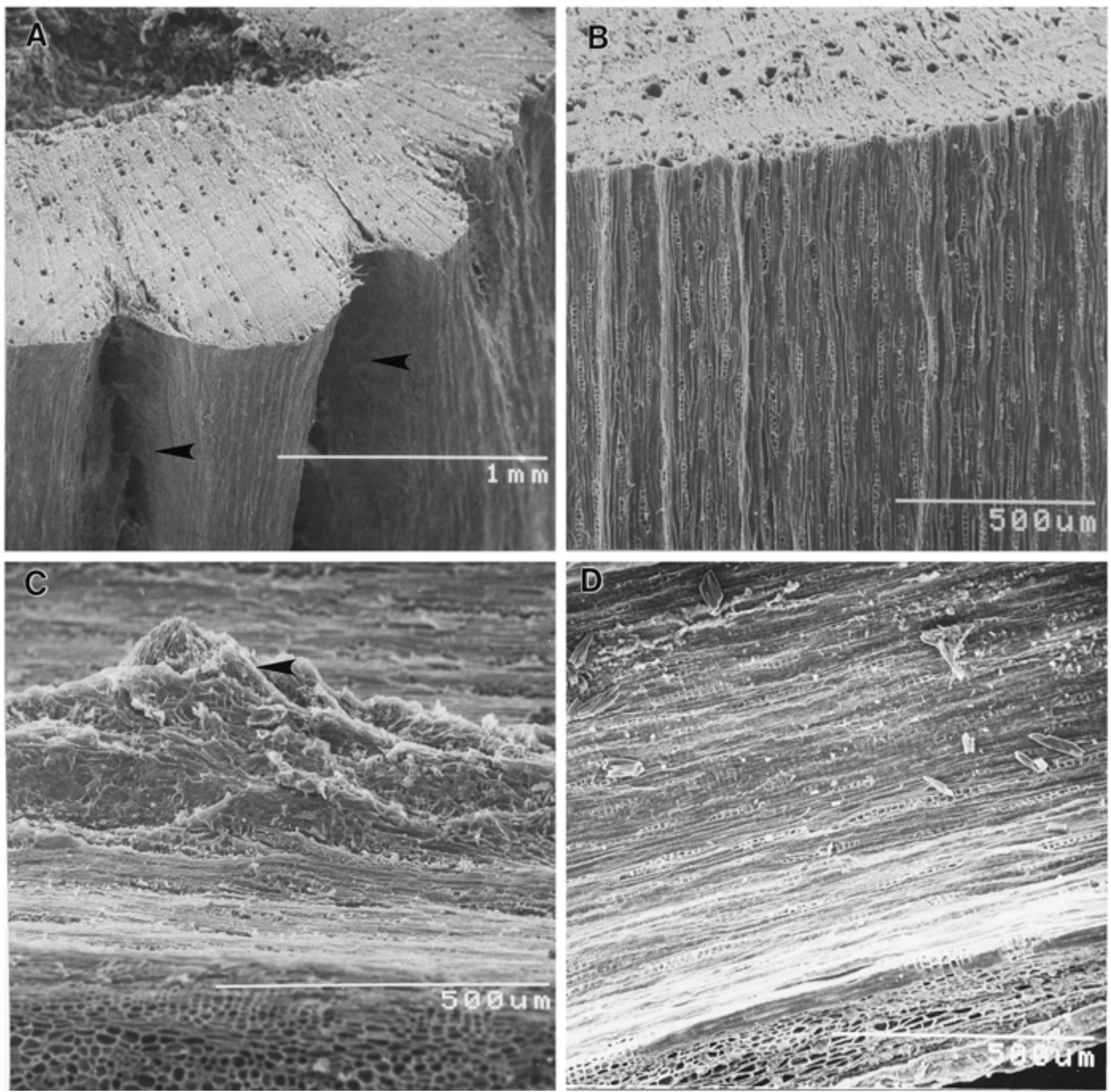

Fig. 1. Scanning electron microscopy of A, Citrus tristeza virus (CTV) isolate PB234 (B380)-infected wood, B, healthy wood, C, PB234 (B380)-infected bark, and $\mathbf{D}$, healthy bark. 
scanning electron microscopy (SEM) were post-fixed in $2 \%$ osmium tetroxide in $0.066 \mathrm{M}$ phosphate buffer, air dried, mounted, and sputter coated with gold/palladium.

\section{RESULTS}

SEM. The severe stem pitting of the wood (xylem) from CTV isolate PB 234infected citrus was shown clearly (Fig. 1A) compared with normal, healthy wood (Fig. 1B). In some wood pits, a yellow gum-like material was seen when the bark was removed from the wood. This substance was seen in the scanning electron micrograph as material adhering to the vessel walls (Figs. $1 \mathrm{~A}$ and 2). In the wood pit, normal xylem and ray structure were not present. When the bark tissue was removed from the wood, the cambial surface showed an ingrowth of cells which were protruding into the wood pit (Fig. 1C). No such wood pitting or ingrowth of the phloem tissues was found in the healthy tissue sampled (Fig. 1D).

Light microscopy. In sections of healthy bark tissue (Fig. 3A) and in sections of PB234 (B380)-infected bark tissue where no phloem ingrowth was present (Fig. 3B), normal cambium, phloem, and phloem parenchyma tissues were found. In the infected bark, in the area adjacent to the phloem ingrowth, normal cambium, phloem, and phloem parenchyma also were seen. However, in the phloem ingrowth (Fig. 3C), the cambium appeared to be open or missing, and an unorganized growth of phloem tissue and phloem parenchyma cells occurred. When Azure A was used to stain cryosections of infected bark tissue, numerous CTV inclusions were clearly visible (Fig. 3D and E, arrows). No inclusions were present in the sections from healthy bark. Most of the inclusions were found in the phloem ingrowth (Fig. 3E). In the larger phloem ingrowth areas, cell walls appeared to thicken and the collapse of some cells was seen.

TEM. The appearance of cambial tissue of both healthy (Fig. 4A) and CTV-infected (Fig. 4B) bark was similar. In the phloem ingrowth (Fig. 4C), the cells lacked organization and no cambium was found. The cell walls were thickened and some cells appeared to have lost their contents and collapsed (Fig. 4D and E). More P-protein (phloem protein), a normal host component and starch were observed in the infected tissue, especially the cambium. Pprotein is a normal constituent in the phloem sieve elements of plants. Depending on the plant species, it appears in various forms, ranging from a network of fibers to discrete crystalline bodies. Larger numbers of mitochondria were present in the phloem ingrowths than in the cambium of either healthy or infected bark tissue.

\section{DISCUSSION}

The histology of symptoms produced by CTV, like that of many other virus diseases of woody plants, has not been fully studied utilizing light microscopy, SEM, and TEM. The establishment of a cause and effect relationship of a single systemic pathogen often is difficult with woody plants. The stem pitting in sweet oranges and in other citrus species is well documented in the literature as a symptom produced by some CTV isolates (14). Our use of a single aphid-transmitted CTV subisolate that was transmitted multiple times and produced identical stem pitting symptoms eliminates the possibility of a mixture of pathogens that elicit this symptom.

In citrus, the cambial initiatives are difficult to distinguish from their recent derivatives; therefore, this area often is referred to as the cambial zone. In the cambial zone of normal (healthy) citrus tissues, cambial derivatives expand by tangential divisions of the cambial initials and gradually assume the characteristics of the various xylem and phloem cells. The tangential orientation of division during the formation of the xylem and phloem causes the arrangement of cambial derivatives into radial rows, which persists in the developing vascular tissue. A change in the cellular structure of both the xylem and phloem of sweet orange infected with a severe orange stem pitting CTV isolate was found in this study. The pitting in the xylem and the coinciding formation of phloem ingrowths into the xylem probably occurs because of an over production of phloem and phloem parenchyma tissue and a lack of production of normal xylem. This may be due to a lack of normal cambium in these areas. In the area of the phloem ingrowths, the cells no longer are arranged into radial rows and appear as a disorganized group of sieve elements and phloem parenchyma. Normal-appearing cambium was found outside these phloem ingrowth areas.

A high number of CTV inclusions was seen in the phloem ingrowth areas. This may mean that more virus may be present in this area of abnormal phloem tissues. The disruption in normal cambial activity and the production of phloem ingrowths and wood pits containing abnormal vessels may ultimately cause stunted trees and smaller fruit.

In 1969, Schneider (21) concluded that, in citrus hosts which develop symptoms of wood pitting and vein clearing (e.g., Mexican lime and sweet orange; no data presented), the vascular cambium was affected, and many of the cambial cells and their immediate derivatives became chromatic or hypertrophic. A mass of hypertrophic parenchyma cells with occasional chromatic cells formed where the xylem and phloem usually form. The bark, when pulled from the wood, left a trench where the abnormal tissue was located. The chromatic cells that Schneider reported were probably CTV inclusions, and the mass of hypertrophic cells were probably the phloem ingrowths reported in this study. However, the phloem ingrowths in our study did not contain hypertrophic cells.

Previous studies on apple trees affected with stem-pitting virus $(11,23)$ utilized light microscopy observations to visualize the changes in the xylem, phloem, and cambium. Abnormalities in the phloem included distortion, collapse and necrosis of the sieve tubes, an increase in the num-

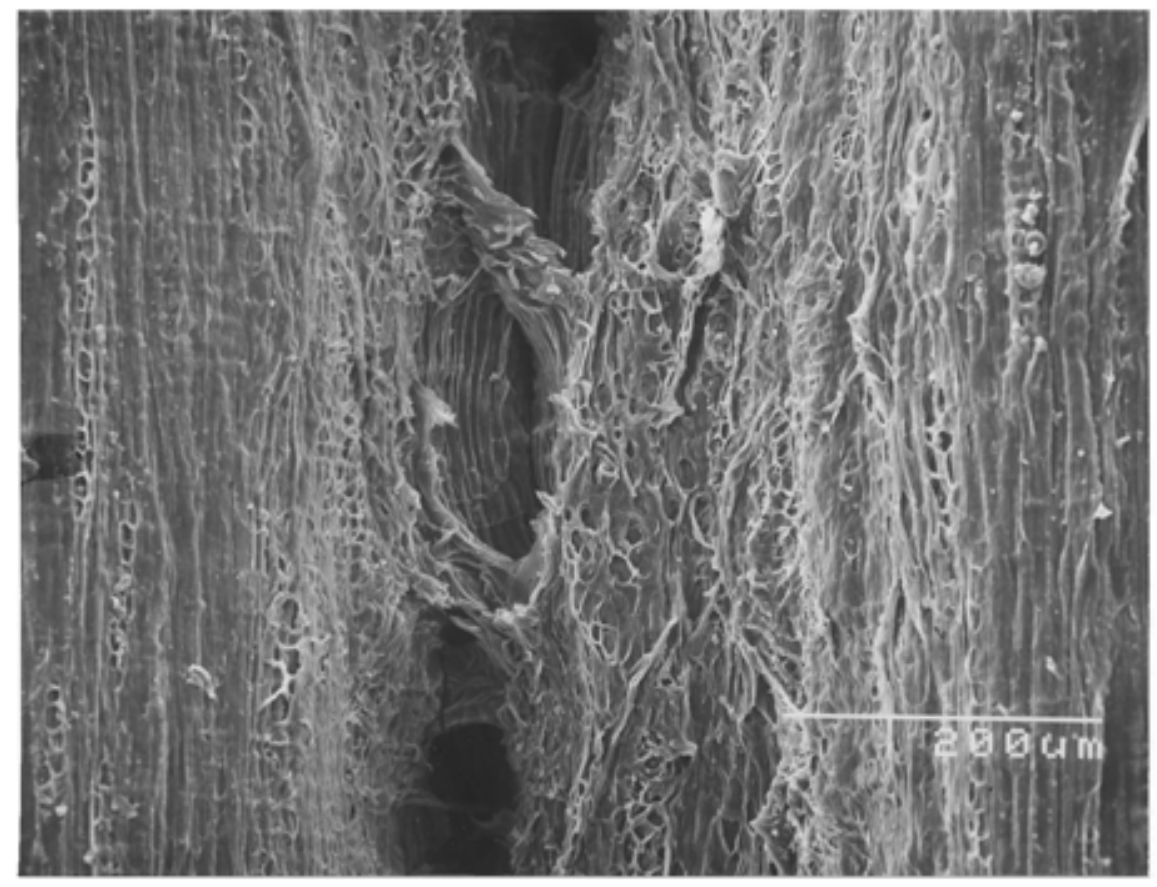

Fig. 2. Scanning electron microscopy of the gum material found in the pits of PB234 (B380)infected wood. 

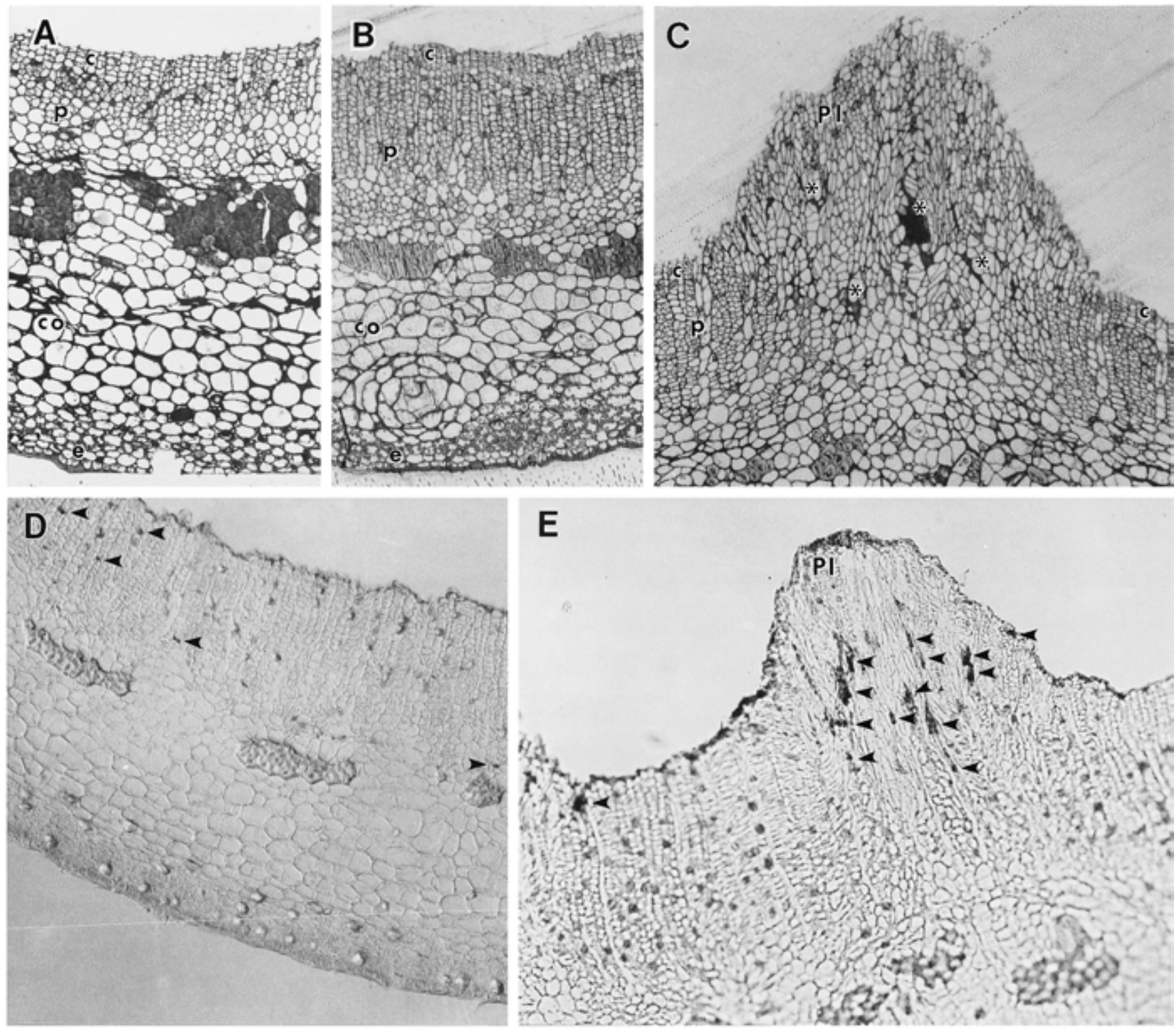

Fig. 3. Light microscopy of A, healthy bark and PB234 (B380)-infected bark B, without and $\mathbf{C}$, with phloem ingrowths. Fewer inclusion bodies in sections stained with Azure A are found in areas $\mathbf{D}$, without than $\mathbf{E}$, with phloem ingrowths. Arrows indicate inclusion bodies. Magnification $\times 114 ; \mathrm{c}=$ cambial zone, $\mathrm{p}=$ phloem, $\mathrm{co}=$ cortex, $\mathrm{e}=$ periderm, $\mathrm{PI}=$ phloem ingrowth, $*$ indicates thickened and collapsed cells.

ber of phloem parenchyma cells, and abnormal and disorganized phloem rays. Similar changes were seen in the phloem ingrowth areas of the citrus tissue examined in this study using both light microscopy and TEM. Phloem cells were thickened and collapsed and the typical phloem ray structure in healthy and in the unaffected areas of infected tissue was not present.

The effect of stem pitting on water and nutrient transport and eventually on the production of stunted trees and smaller fruit still needs to be studied.

\section{ACKNOWLEDGMENTS}

We thank J. Miller, USDA-ARS, FDWSRU, Fort Detrick, Frederick, MD, for greenhouse technical assistance.

\section{LITERATURE CITED}

1. Anonymous. 1950. Stunt bush or stem pitting:

A serious disease of Marsh grapefruit. Agric.
Gaz. N. S. W. 61:365-366.

2. Bar-Joseph, M., Garnsey, S. M., Gonsalves, D., Moscovitz, M. Purcifull, D. E., Clark, M. F., and Lobenstein, G. 1979. The use of enzyme-linked immunosorbent assay for detection of citrus tristeza virus. Phytopathology 69:190-194.

3. Barrat, J. G., Mircetich, S. M., and Fogel, H. W. 1968. Stem pitting of peach. Plant Dis. Rep. 52:91-94

4. Broadbent, P., Brlansky, R. H., and Indosto, J. 1996. Biological characterization of Australian Isolates of citrus tristeza virus and separation of subisolates by single aphid transmissions. Plant Dis. 80:329-333.

5. Costa, A. S., Grant, T. J., and Moreira, S. 1950. A possible relationship between tristeza and the stem pitting disease of grapefruit in Africa. Calif. Citrogr. 35:504, 526-528.

6. Garnsey, S. M., Youtsey, C. O., and Bridges, G. D. 1979. Reaction of eight citrus varieties topworked on Milam trees with severe stem pitting symptoms. Proc. Fla. State Hortic. Soc. 92:18-20.

7. Ghanem-Sabanaadzovic, N. Abou, Mahboubi,
M., Di Terlizzi, B., Sabanadzovic, S., Savino, V., Uyemoto, J. K., and Martelli, P. Molecular detection of a closterovirus associated with apricot stem pitting in southern Italy. J. Plant Pathol. In press.

8. Goheen, A. C. 1988. Rupestris stem pitting Page 53 in: Compendium of Grape Diseases. R. C. Pearson and A. C. Goheen, eds. American Phytopathological Society, St. Paul, MN.

9. Grant, T. J., Costa, A. S., and Moreira, S 1951. Tristeza disease of citrus in Brazil. Calif. Citrogr. 36:310-311, 324-326, 328-329.

10. Hansen, A. J. 1995. Tomato bushy stunt virus Page 78 in: Compendium of Stone Fruit Diseases. J. M. Ogawa, E. I. Zehr, G. W. Bird, D F. Ritchie, K. Uriu, and J. K. Uyemoto, eds. American Phytopathological Society Press, St. Paul, MN.

11. Hilborn, M. T., Hyland, F., and McCrum, R. C. 1965. Pathological anatomy of apple trees affected by the stem-pitting virus. Phytopathology 55:34-39

12. Hughes, W. A., and Lister, C. A. 1949. Lime disease in the Gold Coast. Nature 164:880.

13. Hughes, W. A., and Lister, C. A. 1953. Lime 


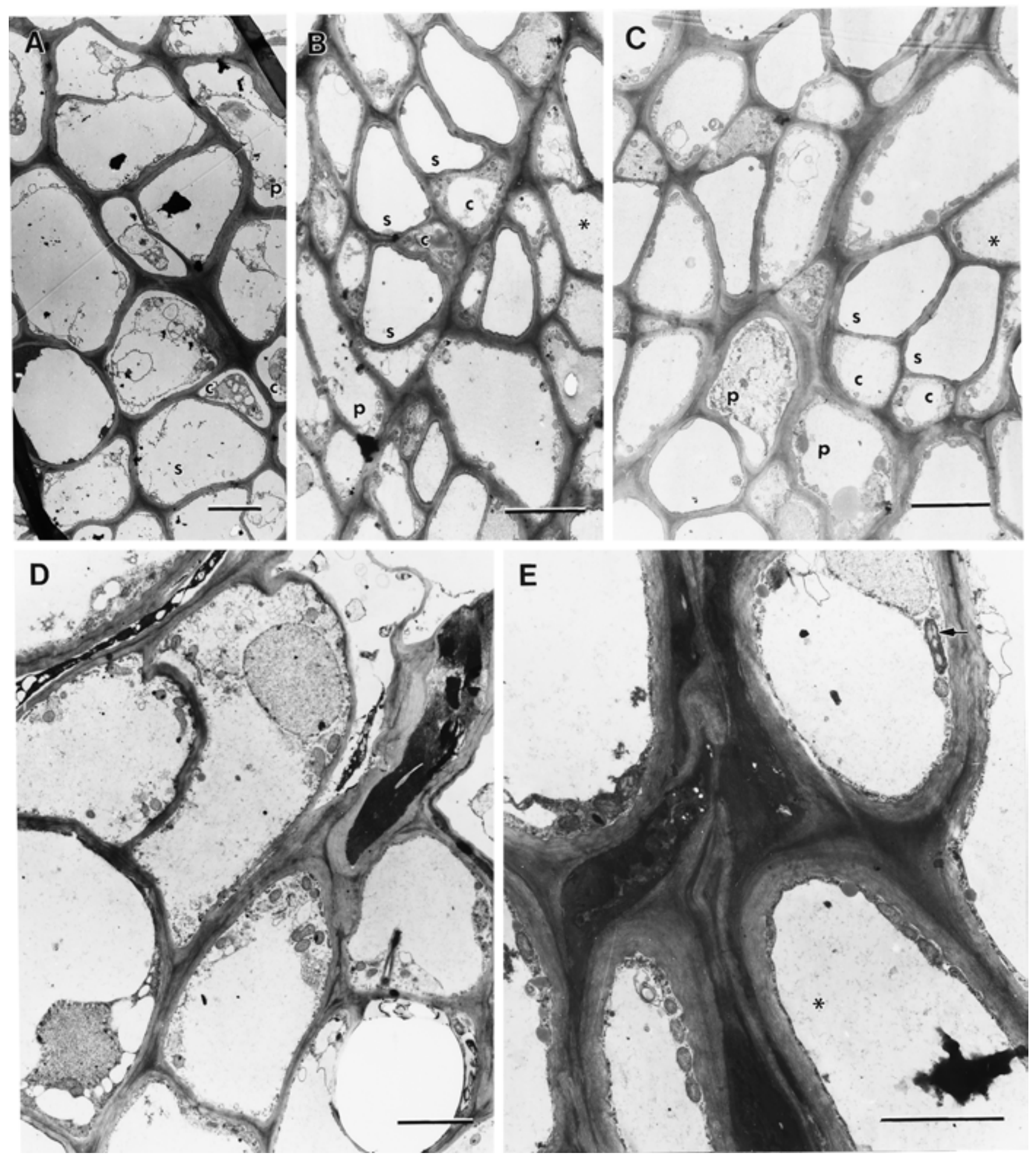

Fig. 4. Transmission electron microscopy of A, healthy cambium, B, PB234 (B380)-infected cambium, C, PB234 (B380)-infected phloem ingrowth with $\mathbf{D}$, thickened and $\mathbf{E}$, collapsed cells. Bar $=5$ microns; $\mathrm{s}=$ sieve element, $\mathrm{c}=$ companion cell, $\mathrm{p}=$ phloem parenchyma, $*$ indicates cells containing $\mathrm{P}$ protein, arrow indicates starch.

dieback in the Gold Coast, a virus disease of the lime, Citrus aurantifolia (Christmann) Swingle. J. Hortic. Sci. 28:131-140.

14. Lee, R. F., and Bar-Joseph, M. 2000. Tristeza. Pages 61-63 in: Citrus Compendium. L. W. Timmer, S. M. Garnsey, and J. H. Graham eds. American Phytopathological Society Press, St. Paul, MN.

15. Marini, D. B., Zhang, Y. P., Rowhani, A., and Uyemoto, J. K. Etiology and host range of plum bark necrosis-stem pitting agent. Plant
Dis. 86:415-417.

16. McClean, A. P. D. 1950. Possible identity of three citrus diseases. Nature 165:767-768

17. Mircetich, S. M., and Fogel, H. W. 1969. Stem pitting in Prunus spp. other than peach. Plant Dis. Rep. 53:7-11.

18. Mircetich, S. M., Moller, W. J., and Nyland, G. 1977. Prunus stem pitting in sweet cherry and other stone fruits in California. Plant Dis. Rep. 61:931-935.

19. Oberholzer, P. C. J., Mathews, I., and Stiemie,
S. F. 1949. The decline of grapefruit trees in South Africa. A preliminary report on socalled "stem pitting". Union S. Afr. Dep. Agric. Sci. Bull. 297:1-18

20. Schneider, H. 1959. The anatomy of tristezavirus-infected citrus. Pages 73-84 in: Citru Virus Dis. J. M. Wallace, ed. University of California Div. Agric. Sci., Berkeley, CA.

21. Schneider, H. 1969. Pathological anatomies of citrus affected by virus diseases and by apparently-inherited disorders and their use in diagno- 
ses. Proc. First Int. Citrus Symp. 3:1489-1494.

22. Stouffer, R. F., Lewis, F. H., and Soulen, D. M. 1969. Stem pitting in commercial cherry and plum orchards in Pennsylvania. Plant Dis. Rep. 53:434-438.

23. Tukey, R. B., and Mink, G. I. 1961. Morphology and anatomy of stem-pitting in Virgina crab. Am. Soc. Hortic. Sci Proc. 78:8-15.

24. Uyemoto, J. K., Luhn, C. L., Griesbach, J. A., and Grant, J. A. 1995. Occurrence and control of cherry stem pitting disease. Plant Dis. 79:2275-2281.

25. Vogel, R., and Bove, J. M. 1968. Cristacortis, a virus disease inducing stem pitting on sour orange and other citrus species. Pages 221228 in: Stem Pitting in Orlando Tangelo Caused by an Unknown Pathogen are Similar to Those Produced by Citrus tristeza Clos- terovirus. Proc. 4th Conf. Intl. Org. Citrus Virol. J. F. L. Childs, ed. University of Florida Press, Gainesville.

26. Wallace, J. M. 1951. Recent developments in studies of quick decline and related diseases. Phytopathology 41:785-993.

27. Webber, H. J. 1943. The "tristeza" disease of sour-orange rootstock. Proc. Am Soc. Hortic. Sci. 43:160-168. 